\title{
The true costs of US agricultural dumping
}

\section{cambridge.org/raf}

Themed Content: U.S. Farm Bill: Policy, Politics, and Potential

Cite this article: Murphy S, Hansen-Kuhn K (2020). The true costs of US agricultural dumping. Renewable Agriculture and Food Systems 35, 376-390. https://doi.org/10.1017/ S1742170519000097

Received: 8 March 2018

Revised: 28 September 2018

Accepted: 2 January 2019

First published online: 1 April 2019

\section{Key words:}

Crop prices; dumping; farm bill; policy; sustainability

\section{Author for correspondence:}

Sophia Murphy, E-mail: sophia@foodresilience. net

(c) Cambridge University Press 2019

\section{Sophia Murphy ${ }^{1}$ and Karen Hansen-Kuhn ${ }^{2}$}

${ }^{1}$ University of British Columbia and the Institute for Agriculture and Trade Policy, Vancouver, Canada and

${ }^{2}$ Institute for Agriculture and Trade Policy, Washington, DC

\section{Introduction: what is dumping?}

Dumping is a term used in trade circles to refer to the practice of selling goods abroad for less than they are sold for at home. Dumping is legal under the World Trade Organization (WTO) agreements unless a member state can prove not just that dumping has occurred, but also that it is harming domestic producers. Governments may help a sector make the dumping case, but there must be a wronged party: commercial actors who can demonstrate how their economic interests are being hurt. In theory, economies should count underpriced goods as a good thing because they raise consumer welfare by lowering costs. In practice, however, dumping hurts domestic producers' economic interests. And domestic producer organizations have more political clout than do consumers, who are usually ignorant or indifferent to relatively small welfare gains that are spread over millions of people. Lost livelihoods are more politically salient (Mahé and Roe, 1996). Trade agreements include provisions to counter dumping if the complainant proves their case, for example, with additional tariffs or quotas on import volumes. And some countries, prominent among them the USA, have anti-dumping measures in their domestic legislation as well. Dumping is usually assumed to be a conscious strategy. For example, recognizing that an export market is more competitive than their domestic market, a firm might choose to sell their good for less in that market than they charge in their home country, where they may enjoy a less competitive market. The strategy might be temporary, used as a way to establish a competitive share of the market, or to drive competitors out of business. Or it might remain in place for a long time, depending on how financially viable the strategy is. The dumping discussed in this article, however, is not a conscious strategy so much as the result of a confluence of policy choices.

The Institute for Agriculture and Trade Policy (IATP) first published a policy paper that documented the dumping of US-grown agricultural commodities in international markets in 1998, following a methodology first laid out by Mark Ritchie, who was President of IATP at the time (DiGiacomo, 1998). In the piece, the author (Gigi DiGiacomo) followed Mark Ritchie's approach and argued that dumping in the context of US agricultural commodities should be defined differently than the deliberate strategy of an aggressive exporter. Instead, DiGiacomo used the definition of dumping provided in the General Agreement on Tariffs and Trade (GATT) that was intended for situations in which the price of a good does not reflect what the GATT refers to as the good's 'normal value'. This might be, for example, because governments are setting or constraining prices in some way, as has been common historically for staple food prices in many countries, or because a monopoly controls the market. In this situation, market prices are not considered to provide an accurate indicator. Article VI of GATT includes a provision instead for the construction of a reference price based on the cost of production and related expenses. In successive papers on the prevalence of dumping in US agricultural commodity markets, IATP innovated a dumping calculation that used data from official government sources to track production costs, farmgate prices, an estimated transportation cost and export prices for five commodities: wheat, rice, maize (called corn in the USA) and cotton \{DiGiacomo:1998vp, Murphy:2005ui, Ritchie:2000tz\}. 
IATP created a 'dumping percentage' by comparing how much less the export price is than the cost of production plus transportation.

IATP argued that this price construction to determine dumping is appropriate given the extent of the US federal government's interventions in commodity markets, as well as the government's failure to enforce competition rules, allowing already dominant grain traders to continue to consolidate their market power \{Murphy:2008el, Hendrickson:2008iy\}. Economic power in agricultural markets in the USA has grown increasingly concentrated over the last several decades, in both the input sectors such as farm equipment, seeds and chemicals, and in the commodity trader, processor and retail sectors as well (Murphy, 2006; Hendrickson and Heffernan, 2007; Heinrich Böll Stiftung, Rosa Luxembourg Stiftung, Friends of the Earth Europe, 2017). Farmers came to rely on a series of strategies to make ends meet, among which an evolving series of government programs played a central role. They also relied on off-farm employment and exploitative use of their own labor. IATP dumping numbers suggested that US farmers were operating at a loss for years at a time, to their own detriment and to the detriment of growers elsewhere in the world whose prices were depressed by this US phenomenon (Ritchie et al., 2000; Murphy et al., 2005).

This article looks again at this problem in more detail, adding over a decade's worth of new data that includes the period of high and volatile commodity prices from 2007 to 2013, during which time the level of dumping fell and even disappeared at some points. Altogether, we present data from 1990 to 2017 (see Fig. 1). With world commodity prices significantly lower again in 2018, dumping is again on the rise, yet the debates on a new US Farm Bill give no sign of tackling the issue. It is thus a good moment to ask a few questions. To what extent has this pricing discrepancy between costs of production and export prices persisted since 2005? What are the causes and consequences of dumping, and to what extent are government interventions in the Farm Bill to blame? How have the numbers changed over the years that IATP has documented the problem (1990-2017) and how might the problem evolve in the future? First, we explain how IATP calculates dumping in more detail.

\section{Method}

IATP has calculated the extent of US dumping of wheat, soybeans, corn, rice and cotton periodically since 1998 (DiGiacomo, 1998; Ritchie et al., 2000; Murphy et al., 2005). IATP uses the definition of dumping established in the GATT for markets in which the market price may not reflect 'normal value' (e.g., because of the presence of significant public subsidies). In such cases, normal value must be constructed:

...the 'constructed value' of the product, which is calculated on the basis of the cost of production, plus selling, general, and administrative expenses, and profits. (Article VI of GATT 1994)

Using data from the US Department of Agriculture (USDA) and the Organization for Economic Cooperation and Development (OECD), IATP calculates dumping by comparing production costs and export prices, looking at each commodity separately. Over time, IATP analysis showed a consistent pattern of dumping for each of the commodities studied over the period from 1990 to 2003 (Murphy et al., 2005). In 2003, dumping rates for those goods ranged from $10 \%$ for corn to $28 \%$ for cotton: in other words, the export price of the major agricultural commodity crops was anywhere from 10 to $28 \%$ less than the cost of production. At these levels, dumping was significant and depressed prices for agricultural commodities, affecting the profits of farmers who were selling into export markets, as well as of farmers selling in the local markets of importing countries.

In the new calculations of dumping rates presented here, the authors relied on the same methodology as in the 2003 and 2005 analyses, adding the costs of production to the government support allocated to each of the five crops and estimating transportation costs to the exit port. This generates an estimate of the full cost of production, which the authors then compare to export prices. In most cases, the authors are still able to use the same data sources so that they can compare the trends in prices in the past with those happening in more recent years.

The cost of production is drawn from USDA Economic Research Service tables on commodity costs and returns (Economic Research Service, n.d.). Those tables include operating costs such as seeds and fertilizer, as well as allocated overhead costs. While these tables do not list profits (profit is usually included as a component of dumping calculations to determine normal value under GATT rules), they do include the opportunity costs of land and labor, i.e., what those resources could have earned if they had been put to other uses. The authors argue opportunity costs provide a measure similar to profits in that they reflect economic returns from inputs. To the operating and opportunity costs, they added the cost of government support to produce those crops, as reported to the OECD Producer and Consumer Support Estimates Database (OECD, 2016), which includes the subsidy portions of crop insurance, revenue insurance and credit allocated to each crop. While not a cost in the same sense as fertilizer or other inputs, these subsidies strongly influence farmers' decisions on what crops to plant and are thus an integral part of the determination of how much of which crops are produced and sold (Sumner, 2003; Glauber and Westhoff, 2015).

Estimates of processing and transportation costs as the commodity goes from field to port are the most problematic part of the IATP dumping calculation. Shippers and handlers' contracts are proprietary while, for most grain traders, transportation costs are internal to the business because they own storage terminals, trucks, barges and rail cars. Moreover, the crops are grown at and distributed to diverse places, undermining the accuracy of average numbers. Nonetheless, transportation is a real part of the total cost and cannot be ignored. IATP estimates transportation based on the difference between the price paid at a typical site of production for that crop, and the price paid at the port of export.

More specifically, we used the yearly average of weekly prices paid in Kansas (wheat), Iowa (soybean), Illinois (corn) and Arkansas (rice) and the Freight On Board price at Gulf coast ports, as reported in USDA Agriculture Marketing Service Transportation Analysis Table 2: Market Update: US Origins to Export Position Price Spreads, and USDA Economic Research Service, Rice Yearbook (Agricultural Marketing Service, n.d.). In the case of cotton, we used the National Cotton Council of America's A Index of global prices, which is consistent with USDA figures (National Cotton Council of America, n.d.). We were not able to identify comparable estimates of prices at the point of production, so we do not include transportation costs for cotton. We recognize that these are rough estimates of the real transportation and handling costs. Going forward, it would 


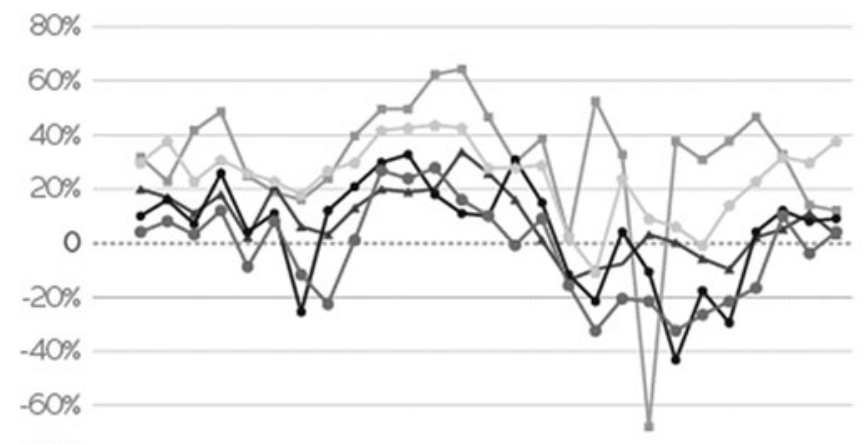

$-80 \%$ 8$\rightarrow$ Cotton $\rightarrow$ Rice $\rightarrow$ Soybeans $\rightarrow$ Wheat $\rightarrow$ Corn

Fig. 1. Dumping rates for major US commodities.

be important to try to discover better data on which to base these costs, as they are an important element of the dumping calculation.

\section{Findings}

Figure 1 illustrates the results of the dumping estimates. The dumping rates from 1990 to 2003 are based on IATP's earlier calculations. With some exceptions, they show a consistent pattern of dumping. Adding in the new calculations from 2005 to 2017, we see a return to the patterns of the past. As prices started to fall again after the price spikes of 2007-2008 and the 2011-12 drought in the USA, rates of dumping increased. While there have been fluctuations in some years, in general we see a return to US dumping in export markets by 2013. As of 2017, the rates of dumping stood at $38 \%$ for wheat, $9 \%$ for corn, $4 \%$ for soybeans, $3 \%$ for rice and $12 \%$ for cotton.

Another way to understand these figures is that despite the pause in dumping during the price shocks of 2007-2008, and 2011, the structural factors that allowed dumping to arise in the first place have persisted, so that the problem recurred as overproduction began to replenish stocks and calm buyers' fears, which lowered international market prices. The food price crisis might have been expected to change public policy in agriculture. The G7 and the G20 met and made joint declarations and a number of developing countries began to invest again more seriously in agriculture \{Murphy:2013tr, Clapp:2013fo, Wise:2012ui\}. But agricultural policies did not change in the USA. The period of high and volatile prices had many causes. They included low levels of stocks, strong underlying demand growth as levels of poverty fell in many parts of the world, and the rapid emergence of large markets for biofuels, which changed expectations of future prices in the market (Abbott et al., 2008, 2011; Headey and Fan, 2008; High Level Panel of Experts on Food Security and Nutrition, 2011). Even though the food price crisis gave rise to a more alarmist view of future food availability, based on projected demand and constraints on expanding production (FAO, 2009), the period of higher prices seemed to curb interest in programs that would address over-supply. Despite warnings that higher prices would trigger another period of higher production and lower prices unless the government intervened, the government continued to pursue a policy of underwriting intensive

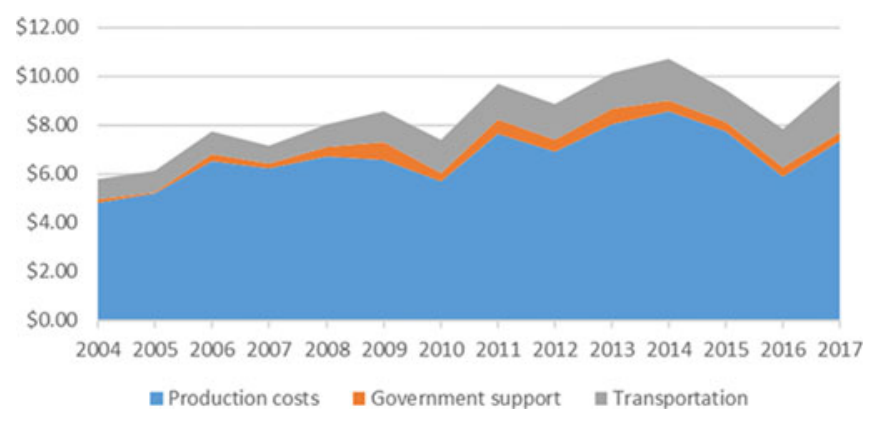

Fig. 2. Total cost of wheat (in dollars per bushel).

production at considerable public expense without regard to market structure and concentrated corporate interests (Murphy et al., 2012; Wise and Murphy, 2012).

The international debate on dumping in agriculture, particularly at the WTO, has focused on the role of government subsidies and limits to market access ('protectionism'). The causes of dumping in the US context, however, are more complex. Figure 2 (below) illustrates the relative sizes of production costs, subsidies and transportations costs for wheat. Even with the changes in the 2014 Farm Bill, and a move to income insurance policies, the relative size of wheat subsidies in relation to the overall costs of production has remained fairly constant. The picture is similar for corn and soybeans. In the case of rice, transportation costs are relatively higher, but the pattern is the same. Both subsidies and dumping are linked to market prices, but they do not track precisely; subsidies are not large enough, nor do they correlate closely enough, to explain dumping fully. In the years IATP has tracked dumping, successive Farm Bills have changed the basis of support significantly. In 1996, the Farm Bill sought to separate payments from production and introduced decoupled payments, so-called because the payment was based on historic rather than actual production. In 2002, the Farm Bill returned, somewhat, to earlier programs such as countercyclical payments linked to crop prices, but not at levels that covered production costs. In the 2008 Farm Bill, the government began to look at other ways to support income rather than crop levels, and in 2014, the government turned to income and price insurance. Some of the measures are more sensitive to price than others (rising when prices fall) but with the introduction of weighted averages of recent years, farmers are concerned that the benefits of the program will be eroded gradually as successive low-price years push payments down.

The issue for dumping is not only the amount of the subsidies, but the incentive they create to produce certain crops that then require export markets to keep prices buoyant in the face of flat domestic demand. This is coupled with a lack of policy interventions to redress the effects of oligopsony power in the market (there are very few buyers in relation to the number of farmers who are selling) (Hendrickson and Heffernan, 2007). The interlocking set of contributing causes includes a government intent on not challenging agribusiness market power, or establishing effective production limits, and relying on agricultural support programs that use public funds to make up shortfalls in farm income for particular commodity crops, such as rice, corn and wheat. These actions combine to generate surplus production that cannot be sold at a profit, which becomes a driver of US trade policy as the government looks to open new export markets, encouraged by the multinational grain traders. The imperative of 
expanding exports shapes US Government demands for access to other countries' markets. Yet the government refuses to address the trade distortions created by oversupply and dumping in international markets. This picture has been further confused in the past year by the Trump Administration's imposition of steel tariffs, which prompted China to retaliate with tariffs on sorghum and soybeans, shrinking outlets for US exports and depressing prices (Bloomberg News, 2018).

\section{How much do US exports matter?}

The USA is an international agricultural powerhouse. It is the third largest producer of agricultural commodities, globally, after China and India, and the world's largest agricultural exporter ${ }^{1}$ \{WTOStatisticsDatab:tc, accessed 26 September 2018\}. It is the largest producer of corn and soybeans, the third largest producer of wheat and cotton, and the 11th largest producer of rice \{FAOSTAT:vt, accessed 26 September 2018\}. In the $18 \mathrm{yr}$ IATP has tracked dumping, the amount of food traded in international markets has grown significantly, and the US share of that total has shrunk. Brazil now rivals the USA as a soybean exporter, while Russia is poised to overtake the USA as a wheat exporter. The share of US agricultural exports has almost halved in the past two decades, from 23\% of global value in 1995 to $12.5 \%$ in 2013 (Good, 2017). Yet US agricultural commodities still make up a huge share of international markets. The USA is the world's largest exporter by value of wheat, corn, soybeans and cotton, and the fourth largest exporter of rice in international markets (FAO, n.d.). Since IATP began this analysis in 1990, all these crops have been dumped well over half the time (see Fig. 3).

\section{Why does it matter?}

Dumping matters for at least three reasons. First, dumping hurts US producers who sell their product into markets that are controlled by just a handful of agricultural commodity trading corporations. When farmers cannot get back their production costs from the market, they are forced to rely on other strategies to survive, whether it is off-farm employment, government subsidies or under-valuing their labor (Ray et al., 2003; Rosset, 2006). As this paper documents, the prices US farmers get for their crops, on average, are in many years below their average cost of production. The price gap lessened, and even disappeared briefly, during the period of high and volatile commodity prices from 2007 to 2013. But prices in international markets are down again and in 2018 are the lowest they have been since 2002. Net farm income in the USA is down by $50 \%$ since 2013 (Schnepf, 2017). The US Department of Agriculture Economic Research Service (ERS) projects that median farm income, estimated at $-\$ 940$ in 2016 , will decline to $-\$ 1316$ in 2018 , noting that, 'In recent years, slightly more than half of farm households have had negative farm income each year' (Economic Research Service, 2018). ${ }^{2}$ The economic consequences of a system that reinforces dumping are felt by US commodity growers and their families, their hired workers, and by the rural communities they live in; communities that are deprived of spending that would otherwise support vibrant

\footnotetext{
${ }^{1}$ The 28 member states of the European Union together export more than the USA, so in analysis that compares WTO members, the USA places second after the EU.

${ }^{2}$ The projections do not take into account the potential impacts of the Market Facilitation Program (MFP), announced on July 24, 2018, as the implementation of that program was not yet clear.
}

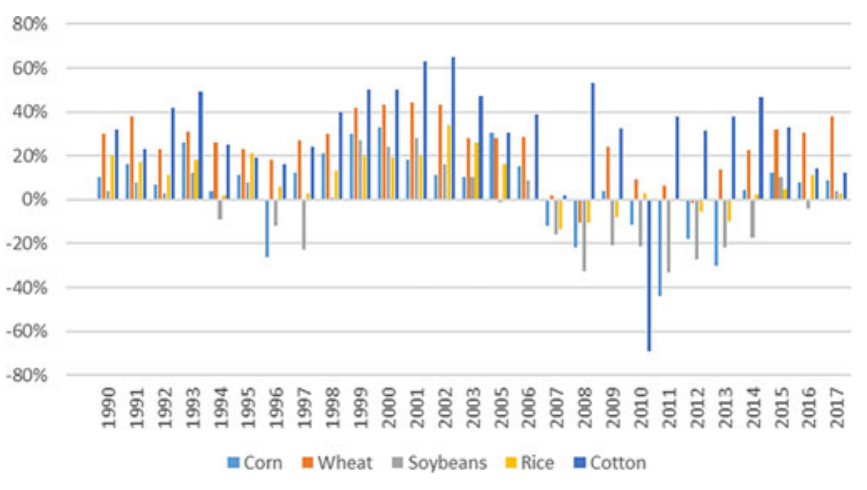

Fig. 3. Trends in dumping over time.

economic life. It is this acute socio-economic crisis in rural areas that provides one of the links among the members of $\mathrm{La}$ Via Campesina, an international federation of farmer and peasant organizations that has included the US National Family Farm Coalition since the mid-1990s. These farmer and peasant organizations have found common cause in a political platform that links every continent; while economists may describe them as competitors, the farmers are inclined to find common ground in selling into oligopsonistic markets wherever they may be located.

Secondly, it undermines the economic viability of farmers in other countries, whether the farmers are growing crops for their domestic markets in importing countries or selling their crops to traders for export in competition with US production (Ray et al., 2003; Wise, 2004; Morrison and Mermigkas, 2014). This is especially a problem for developing countries that rely on agriculture for economic stability because the sector makes up half or more of their employment and the largest share of their GDPsuch countries are typically among the world's poorest. Even countries that do not import US commodities suffer because US exports are large enough to affect world prices, which affect all countries who trade some share of their agricultural production.

Thirdly, dumping undermines the realization of environmental objectives. Agriculture is putting unsustainable stress on a number of planetary boundaries, including genetic diversity and nitrogen (Rockström et al., 2009; Campbell et al., 2017). Care of the natural resource base, including the imperative to protect soil health, water quality and the ecological diversity of farmland, are all squeezed when production is under-valued (Rayner and Lang, 2013). Several factors reinforce a vicious circle, including commodity markets that externalize environmental costs, farmers' attempts to make up on volume what they have lost on value, and the tendency of low prices to drive increasing concentration, hurting new entrants and diminishing competition. The result harms planetary systems and the local ecosystems across the planet that are linked by international trade and investment (High Level Panel of Experts on Food Security and Nutrition, 2017a).

\section{Why does it happen?}

There are three main factors behind dumping. One is the level of market power enjoyed by the companies that provide inputs to farmers, buy commodities and process those commodities into food, animal feed and industrial products. Those actors as a broad group are often referred to as agribusiness. In this paper, 
we focus primarily on the international commodity trading firms that buy grain from farmers and sell it on to other agents around the world, whether processed or still in raw commodity form. Four firms dominate this trade, all of them vertically integrated along the grain value chains: Archer Daniels Midland, Bunge, Cargill and Louis Dreyfus. These four firms dominate US domestic agricultural commodity supply chains, and the international grain trade (Hendrickson and Heffernan, 2007; Hendrickson et al., 2008; Murphy et al., 2012). They are estimated to control $75-90 \%$ of grain trade globally; in many local markets, just one or two firms are present (Clapp, 2014).

Despite this situation, the US Government has failed to limit or reduce the oligopolistic market power of commodity traders (Howard, 2016). Concentrated market power in agriculture is a problem that has prompted Congressional hearings and nationwide listening tours (see the 'Report of the USDA National Commission on Small Farms: A Time to Act' from 1997, or the reports from Senate Hearings ${ }^{3}$ ). It is an old problem-one that in the past has prompted legislative and regulatory action. But successive Farm Bills have come and gone leaving the problem unaddressed, while legislation in other areas, such as the 2000 deregulation of financial services through the elimination of the Glass-Steagall Act, have further strengthened grain traders' economic position (Murphy et al., 2012; Clapp, 2014). Grain traders are heavily involved in commodity processing. They are vertically integrated in the market. This means that the costs at different stages of the commodity value chain remain internal to the firm's operation, including the price of corn purchased on the commodity exchange, the price of the processed products made from that corn at the crushing plant, and the cost of the grain provided to a feed lot operator (Hendrickson and Heffernan, 2007; Murphy, 2008a). The external price discovery mechanisms that markets rely upon for efficiency are missing. Vertically integrated companies are able to capture a disproportionate share of the benefits of cheap grain (Wise, 2005; Wise and Rakocy, 2010).

In effect, agribusinesses that buy and process agricultural commodities have the market power to push prices below the level that would provide a reasonable profit to producers and to appropriate value at the stages of the supply chain under their control. The persistent gap between production costs and the price farmers receive is evidence the market is not correcting. The government payments make it possible for farmers to continue-they muffle the price signal-but they fail to stop dumping. As the authors see it, and as IATP has argued historically, price distortions are built into the earliest point of commodity production, with insurance and other government subsidies serving as a patch that (sort of) keeps the system going.

A second factor is the government subsidies. There is no question that without the subsidies, many more US farms would fail (Ray et al., 2003; Wise, 2005). The negative income reported by ERS and cited above confirms it. The question is whether fewer farms would reduce dumping, which is a factor of the volume of supply, not the number of farms in operation. The longer-term trend is toward consolidation and fewer, larger farms (USDA, 2012).

The third factor links the market power of agribusiness and the government programs. Until 1985, when the Farm Bill policies started to change, the US Government's non-recourse loans

\footnotetext{
${ }^{3}$ https://www.gpo.gov/fdsys/pkg/CHRG-110shrg45064/html/CHRG-110shrg45064. htm From a 2008 hearing of the Senate Judiciary Sub-Committee on Antitrust, Competition Policy and Consumer Rights
}

acted like a buyer of last resort in the market. Farmers knew that if market prices were less than the price foreseen when they borrowed money from the government for their crop, the government would accept their crop in lieu of repayment. This effectively created a price floor that the grain traders (already enjoying significant market power although the markets were not as concentrated then as they are now) had to match or beat (Morgan, 1979). With the elimination of the non-recourse loan, farmers lost a bargaining instrument against the market power of grain traders (Levins, 2000).

\section{Dumping and US farm programs}

In the USA, all the major traded agricultural commodities are produced with significant government intervention. In the aftermath of the Great Depression, the USA established supply management programs to balance markets while keeping farms economically viable. Henry Wallace, US Secretary of Agriculture from 1933 to 1940, had been influenced by a visit to China where he learned about the country's long history of public stockholding as a tool to protect stable food prices and avert famine (Bodde, 1946). US farm programs have changed over the last $50 \mathrm{yr}$, as the USA experimented with dozens of ways to stabilize supply and keep farm prices buoyant, including target prices, non-recourse loans, production quotas, price floors, deficiency payments, payments in kind and land set-asides-not to mention import tariffs. Then, in the 1970s, Nixon's Secretary for Agriculture Earl Butz famously exhorted farmers to plant 'fencerow to fencerow' and was accused of supporting policies that forced farmers to 'get big or get out' (Scholar, 1973). Butz ended the land set-aside policies that were then in place, and moved policies decisively away from supply management toward expanding production and export markets (Hunter, 1989). Already in the 1950s, the US Government had established programs that disposed of cereal surpluses as international food aid, which disrupted local markets in developing countries and created food dependency (Barrett and Maxwell, 2005; Cullather, 2011). Then in the 1980s, the US Government introduced export subsidies to support commercial exports that were threatened by the exponential growth of European production (Wolfe, 1998).

Over several decades, grain traders lobbied to erode price support programs and to encourage trade liberalization. This political role is largely invisible, though some careful histories make note of it. Journalist Dan Morgan's 1981 book, Merchants of Grain, is illuminating. The book covers the origins of five dominant global grain trading firms and brings the story up through the so-called Great Grain Robbery of 1972 and its aftermath (Morgan, 1979). The grain trades from the USA to Russia in that year contributed to a food price crisis in international markets, and brought a series of policy changes in its wake (Shaw, 2007; Timmer, 2010). Brewster Kneen's in-depth study of Cargill is a meticulously documented account of the largest grain trader's international operations and strategies (Kneen, 2002). Agribusiness leaders engaged strongly as funders and members of the pro-trade International Food \& Agricultural Trade Policy Council, too, whose website and policy papers are at http://www.agritrade.org. Unfortunately, the earlier history is not captured there; the organization was founded in 1987, at the time of the Uruguay Round, but the earliest policy papers on the website only date back to 2003 .

The 1985 Farm Bill introduced significant changes in US farm policy, but the most radical break with post-war production 
management was the 1996 Farm Bill, known as 'Freedom to Farm'. The 1996 Farm Bill shifted government policy away from supporting commodity price floors and toward providing farm income support, ostensibly (though imperfectly) decoupled from current planting decisions (Alston and Sumner, 2007). The move satisfied a long-standing demand from commodity traders that the government should not interfere to raise prices. With the end of those programs, however, traders were able to use their market power to pay less for commodities and the government was left with increasing demands from farmers to make up the shortfall in income that resulted. Agribusiness firms also benefitted directly from export subsidies that insulated them from risks and further consolidated their market power. Export subsidies have hardly been used in recent years, partly because prices were more buoyant between 2006 and 2013, compared with the previous several decades, and partly because governments accepted the direction of the WTO negotiations, which were tending toward a prohibition. The USA joined other WTO member states in agreeing to phase export subsidies out completely at the 10th WTO Ministerial Conference, held in Nairobi in 2015 (WTO, 2015).

The rhetoric surrounding the 1996 Farm Bill encouraged farmers to continue to expand production, urging US farmers to 'feed a hungry world' (and in particular China). The government and the multinational grain companies proposed export markets as a way to keep prices buoyant in the face of over-supply. A brief upward spike in some commodity prices (particularly corn) made the 1996 Farm Bill possible, politically (Orden et al., 1999). Yet in the wake of the 1996 Farm Bill reforms, commodity prices resumed their long-standing downward trend. US farmers protested, and the US Government then adopted a patchwork of emergency measures, which was codified in the 2002 Farm Bill, at which point the US Government reintroduced countercyclical payments, albeit at levels much below production costs (countercyclical because payments rose as prices fell, effectively countering the market signal) (Sumner, 2003; Alston and Sumner, 2007). Dumping levels at that time ranged from $11 \%$ for corn to $65 \%$ for cotton (Murphy et al., 2005).

From 2004, a number of factors in international commodity markets started to shift agricultural prices higher. Steady sustained economic growth in many parts of Asia increased demand for animal sourced foods (meat and dairy), and the feed they needed. Mounting concern about the need to contain greenhouse gas emissions created political pressure from environmentalists that converged with farmers and agribusinesses looking to create new markets for agricultural commodities through establishing a market for biofuels. The result in a number of countries, including the USA, was the creation of public mandates and targets to add ethanol and biodiesel to petrol and diesel fuel (Abbott et al., 2008; Murphy, 2008b). The deregulation of commodity futures markets, which had begun in the 1990s, culminated in a major reform in the USA in 2000 that facilitated the entry of banks, pension funds and other financial actors into speculative markets for agricultural commodities (Clapp and Helleiner, 2012; Clapp, 2014). This, in turn generated significantly higher short-term volatility and made it more difficult for producers and commodity processors to predict prices or supplies (High Level Panel of Experts on Food Security and Nutrition, 2011). This growth in demand, coupled with destabilizing financial pressures and a significant drop in the availability of publicly held stocks of cereals such as corn and wheat, left international commodity markets poorly prepared for supply shortfalls arising from poor harvests, as happened in 2007 and again in 2011 (Abbott et al., 2008, 2011; Headey and Fan, 2008).

The 2008 US Farm Bill introduced further changes, including modest limits on countercyclical payments, the expansion of certain conservation programs, and new initiatives to support the expansion of biofuels production (Senate Agriculture, Nutrition and Forestry Committee, 2008). These new Farm Bill measures conformed to WTO rules, but they did nothing to curb the overproduction that ensued when prices again fell following the 20072008 food price crisis. Once again, farmers looked to exports to compensate for falling revenues from low prices, continuing to expand their production. Soybeans provide a dramatic example: in 2005, the USA exported $\$ 2249$ million worth of soybeans to China. In 2014, trade had increased almost sevenfold, to \$14,476 million (Foreign Agricultural Service, n.d.).

The 2014 Farm Bill introduced some significant changes in the way US farm programs work. Direct Payments based on historic land acreage, Countercyclical Payments (which were price-based) and the Average Revenue Election Payments (ACRE), which were based on farm incomes rather than prices, were all phased out. In their place, the government established two new programs: the Price Loss Coverage (PLC) program and the Agricultural Risk Coverage (ARC) program. The PLC program is price-based, providing a payment when national season-average farmgate prices fall below fixed reference prices. ARC is income-based; the program pays out when county average or individual farm-level revenues per acre fall below $86 \%$ of a benchmark that moves according to a 5-yr Olympic average ${ }^{4}$ of national prices and county or farm yields (producers choose whether to use the country average of individual farm when they enroll). Grain and oilseed producers (including peanut growers) can choose which program to enroll in, but once acres are enrolled in the PLC, farmers cannot move them out until the expiration of the Farm Bill in 2018 (Farm Service Agency, 2014).

Farm insurance programs are considered 'non-trade distorting' under WTO rules. Their cost does not count against the spending limits set by the terms of the Agreement on Agriculture (AoA) \{WTO:1994uf, Annex 2\}. Nonetheless, the ruling of the WTO Dispute Settlement Body in 2004 in a case brought by Brazil against US cotton programs found that even domestic support programs that were allowed under the rules could be considered in violation if the programs had the effect of depressing prices in international markets. The USA challenged the ruling, but it was upheld. In 2009, the USA began to make monthly payments to the Brazil Cotton Institute and committed to revise its cotton program (Ridley and Devadoss, 2012). In the final settlement, in 2014 , the USA agreed to pay a further US $\$ 300$ million to the Brazil Cotton Institute \{USTR:2014vr\}. Before 2014, insurance programs were a tiny part of US farm support programs, and they were not counted in the calculations made by the dispute judges. With their significant expansion in the 2014 Farm Bill, however, insurance programs have become yet another way for the US Government to subsidize production, incurring the risk of further legal disputes at the WTO.

Cotton growers have long received substantial subsidies under successive Farm Bills. Economists argue that in the case of cotton, the land might well be used to grow other crops were it not for the protection against imports and the level of payments provided. US

\footnotetext{
${ }^{4}$ In this case, the Olympic average is based on the most recent $5 \mathrm{yr}$ of price information; the highest and lowest prices are discarded, and the remaining $3 \mathrm{yr}$ of data are used to create an average price.
} 
cotton is not as competitive as soybeans and corn. In a simulation of the impacts of the removal of subsidies on various commodities, Ray et al. found that land allocated to cotton would decline by $12-16 \%$, substantially more than other crops (Ray et al., 2003).

US dumping of cotton was not only the subject of a formal WTO complaint by Brazil, but also a countervailing duty ruling by Turkey. Four of the world's poorest countries, Burkina Faso, Mali, Chad and Niger, formed a group-the Cotton Four-to intensify the pressure at the WTO for new rules to tighten disciplines on cotton spending. Although not a food crop, cotton can provide important livelihoods and food security benefits to smallholder producers (Traoré, 2017). Unfortunately, the financial compensation paid to Brazil was not accompanied by a change in US agricultural commodity programs. Dumping continued. African cotton farmers continue to face a highly distorted international market, as do their governments, some of which are heavily dependent on the foreign exchange earned from exports. While global prices are affected by other factors, especially the changing production and consumption patterns in China, there is little doubt that US policies continue to contribute to artificially low global prices (Lau et al., 2015; Traoré, 2017).

The 2014 Farm Bill reshaped the programs supporting cotton farmers into insurance schemes, which were not problematic under the WTO rulings. The result was STAX, the Stacked Income Protection Plan, which provides revenue protection for upland cotton farmers (over $90 \%$ of US cotton production is upland cotton), based on average area yields (e.g., county level) rather than individual farm yields (Risk Management Agency, 2016).

The 2014 Farm Bill raised challenges for WTO compliance. The farm insurance programs are covered under the exempt programs listed in Annex 2 of the AoA that are not included in the Aggregate Measures of Support (AMS) calculations. Yet the US Government notification to the WTO of its spending on agriculture for 2014 listed much of its insurance spending as productspecific AMS, with only some of the spending protected by the de minimis thresholds [if the total cost of a program is $<\%$ of the value of production of that crop, the program is also exempt from the AMS total under the so-called de minimis provisions (WTO, 1994)]. This suggests that the US Government may not try to use that general exemption to continue its support for specific products. Indeed, according to the US Congressional Research Service, 'None of the current suite of farm price and income support programs and shallow-loss crop insurance programs-MLP, PLC, ARC, SCO, STAX, DMPP, ${ }^{5}$ and the sugar program-would qualify for the green box $^{6}$, because they are coupled, partially or fully, to current prices and/or plantings, or receive additional $\mathrm{TRQ}^{7}$ protection from imports (as is the case for US dairy and sugar producers)', (Schnepf, 2017, p 14). Whether or not this is correct, the prospects for relief from dumping through the WTO remain dim. Not only are the talks by and large paralyzed, with the Trump Administration playing a complicating role, but none of the proposals made to date within the context of the Doha negotiating agenda would significantly

\footnotetext{
${ }^{5}$ MLP, Marketing Loan Program; PLC, Price Loss Coverage; ARC, Agriculture Risk Coverage; SCO, Supplemental Coverage Option; STAX, Stacked Income Protection Plan; and, DMP, Dairy Margin Protection Program.

${ }^{6}$ The term 'green box' is WTO jargon for Annex 2 of the Agreement on Agriculture, which lists programs that are exempt from spending limits.

${ }^{7} \mathrm{TRQ}$, tariff rate quota.
}

limit spending on domestic support, nor would they reinvigorate regulations designed to limit supply.

US farm programs are designed to continue large-scale production of agricultural commodities that are fed into whatever market opportunities exist at a given point in time. Those markets may be for food, biofuels, animal feed and for domestic use or export. In the main, Farm Bill programs do not aim to promote stable rural livelihoods, food security or sustainable production (although a few smaller programs along those lines are included). They are designed to increase supplies of agricultural commodities to feed into international supply chains dominated by large transnational corporations, under conditions in which farmers have diminishing power to insist on prices that cover their costs of production. Despite various government conversations, including government hearings and commissions, over the years to address the steady increase in concentrated market power among agribusinesses that provide inputs or buy and process commodities, no new legislation has been passed that addresses the problem.

\section{How have US farmers fared under this system?}

The fact that US farm goods continue to be sold at prices below the cost of production seems counterintuitive, especially given that public subsidies under the Farm Bill are relatively small in comparison to overall costs of production. Examining USDA's Costs of Production for wheat in Table 1 (not counting government support or transportation costs), to take one example, illustrates the full range of costs. In a year of low prices, a farmer will not fully recover expenses such as the cost of his or her own labor (opportunity cost of unpaid labor) or the implied costs of land. 'Capital recovery of machinery and equipment' will in most cases mean paying back loans on those purchases or planning to replace equipment that wears out. A farmer might absorb some of those losses in the short term, but a business cannot run at a perpetual loss. To cover the revenue shortfall, farm families are pushed to seek off-farm work. Often, farm households look to other sources of employment to provide health insurance, too, as the prohibitive cost of individual health care in the USA is a major issue for farmers and their families (Economic Research Service, 2017). We have not included that cost here, but arguably it should be counted as part of total production costs. ${ }^{8}$

Farmers are structurally disadvantaged in the market place and often work at a loss. This in turn benefits agribusiness who are able to integrate the low costs into their value chain, allowing them to consistently make higher profits than farmers (McMichael, 2004). When we look at the cost of production and the movement to port and export, there are profits and losses at various stages along the supply chain, including the concentration of market for seed, fertilizer and other inputs. A significant share of these costs, however, is hidden behind proprietary contracts and vertically integrated supply chains. This leaves the public covering farmers' losses through government assistance such as income transfers (McMichael, 2004; Downey, 2016).

Agricultural economics has shown that farmers will forgo profit and maintain production in the face of losses for a long time. This is a long-observed fact of agriculture that is different than other sectors. Different explanations are offered for this

\footnotetext{
${ }^{8}$ One of the authors heard a representative of a US-based grain trader assert, in public that Canada's public health program should be counted as a subsidy in assessing Canada's domestic support to agriculture.
} 
Table 1. US wheat production costs in dollars per planted acre

\begin{tabular}{|c|c|c|c|}
\hline & 2015 & 2016 & 2017 \\
\hline \multicolumn{4}{|l|}{ Gross value of production } \\
\hline Primary product: wheat grain & 204.80 & 199.64 & 194.46 \\
\hline $\begin{array}{l}\text { Secondary product: silage/straw/ } \\
\text { grazing }\end{array}$ & 9.10 & 8.82 & 8.87 \\
\hline Total, gross value of production & 213.90 & 208.46 & 203.33 \\
\hline \multicolumn{4}{|l|}{ Operating costs } \\
\hline Seed & 15.07 & 14.26 & 13.77 \\
\hline Fertilizer & 40.10 & 34.18 & 30.91 \\
\hline Chemicals & 14.37 & 14.89 & 14.72 \\
\hline Custom operations & 11.10 & 11.08 & 11.35 \\
\hline Fuel, lube, and electricity & 12.43 & 10.90 & 12.98 \\
\hline Repairs & 21.48 & 21.55 & 22.04 \\
\hline Other variable expenses & 0.65 & 0.69 & 0.70 \\
\hline Interest on operating inputs & 0.10 & 0.25 & 0.56 \\
\hline Total, operating costs & 115.30 & 107.80 & 107.03 \\
\hline \multicolumn{4}{|l|}{ Allocated overhead } \\
\hline Hired labor & 2.28 & 2.39 & 2.50 \\
\hline Opportunity cost of unpaid labor & 18.19 & 18.86 & 19.42 \\
\hline $\begin{array}{l}\text { Capital recovery of machinery and } \\
\text { equipment }\end{array}$ & 88.65 & 89.39 & 91.59 \\
\hline Opportunity cost of land & 65.99 & 62.89 & 63.07 \\
\hline Taxes and insurance & 7.76 & 7.24 & 7.36 \\
\hline General farm overhead & 11.28 & 11.37 & 11.59 \\
\hline Total, allocated overhead & 194.15 & 192.14 & 195.53 \\
\hline Total costs listed & 309.45 & 299.94 & 302.56 \\
\hline
\end{tabular}

Source: USDA Economic Research Service Commodity Costs and Returns. Developed from 2009 survey base year. Fertilizer costs include commercial fertilizer, soil conditioner and manure. Other variable costs include cost of purchased irrigation water and straw bailing.

behavior, including culture, and community and family ties, as well as the economic realities such as the lag that results from holding illiquid assets (land and machinery) and growing a commodity that cannot be produced 'just in time'. It is expensive and slow to change production on a farm, especially as crops have become more specialized and farms less diverse. Periods of high prices, if left unchecked, tend to stimulate an over-reaction by farmers, resulting in more production than is warranted by demand (economists call this an 'over-correction'). As a result, price spikes are volatile in the short-term and quickly trend back to lower prices, and high prices remain an exception not a norm (Levins and Cochrane, 1996). The land is an asset that farmers borrow against when they have no capital to invest. Farmers work for themselves and can do without when profits are down. Most farms in the USA depend on a web of income that includes government payments and the earnings of members of the household who work off-farm. Rented land has become a much more common feature of US agriculture, as some land owners choose to hold on to their land title but allow neighbors to realize economies of scale (and run the risks of planting a crop) by working the land. As rural sociologists and scholars of agrarian change have long explored, the motivations for working a farm include personal, cultural and social factors that are poorly captured by micro-economic cost-benefit analysis; farms tend to be family businesses, and the investment includes family and community ties, and knowledge of specific geographies and microclimates (the literature is vast, but the Journal of Peasant Studies and the Journal of Agrarian Change, as well as Agriculture and Human Values are all good repositories of the work, as is the creative writing of John Berger \{Berger:1979vp\}).

Over the last two decades, the scale of production in US agriculture has moved in two opposing directions: toward larger and very large farms, and toward a new generation of micro farms that are responding to emerging urban demand for more locally grown produce. Volatile prices contribute to that polarization, as smallsized farmers are compelled to either sell their land to bigger farms or to buy up their neighbors' land in the hope that expansion will improve returns (Howard, 2016). Bigger farms are better able to absorb risks and their share of US agriculture has grown. US Census data show the marked drop in the number of midsized farms (those with sales between $\$ 25,000$ and $\$ 100,000$ ). At the same time, the number of small farms has increased, many of which produce meat, fruits and vegetables for local markets but on a tiny scale. As of $2012,75 \%$ of farms had $<\$ 50,000$ in sales, while those with more than $\$ 1,000,000$ in sales ( $4 \%$ of the total farms) produced $66 \%$ of total US crop values (USDA, 2012). While the growth in more sustainable local production is a welcome development, small farms remain highly dependent on off-farm income and vulnerable to failure. The absorption of medium-sized, family-owned and operated farms by bigger operators undermines the flow of capital in local economies that historically made agriculture a mainstay of rural economies across the country (McMichael, 2004).

The 2014 Farm Bill programs react to price drops, but they are not designed to resolve them. They compensate farmers when there is a significant drop in commodity prices but do nothing to change the market structures that make farmers price takers in their markets, whether buying from the concentrated farm input supply sector, or selling to commodity buyers. Farm incomes have been falling for the last $3 \mathrm{yr}$ (Schnepf, 2017), and the level of farm debt to income is now the highest since the 1980s (Wilson and Durisin, 2016). Since the payments under the ARC and PLC insurance programs are based on a 5-yr Olympic average for each crop, the persistence of low prices gradually erodes the size of the payments, too (unless, as has happened many times before, the government resorts to emergency payments to avoid the political consequences of the programs' failures). The US Government answer for decades has been to sell trade agreements and projected expanded exports as the way to grow markets and compensate for low prices, but that response has not solved farmers' lack of bargaining power in relation to commodity traders and processors, most of whom are buying from farmers around the globe.

The US reliance on export markets has had negative impacts on farmers in developing countries, too. Under the North American Free Trade Agreement (NAFTA), for example, corn exports to Mexico increased more than $400 \%$ in the first few years of the agreement, disrupting local markets in Mexico. Based on Mexican Census data, Tim Wise estimates that more than 2 million Mexicans left agriculture in the wake of NAFTA's flood of imports, or as many as one-quarter of the farming population (Wise, 2010). Even when dumping rates decreased during the period of high prices, existing public support programs for agriculture in Mexico, as in the USA, tended to 
support the largest farmers and agribusiness interests, rather than the smaller producers who had been the backbones of their rural economies (Fox \& Haight, n.d.).

\section{Who complains about dumping?}

Dumping has generated significant tension in international trade negotiations, particularly at the WTO. The WTO debate focuses on the use of export subsidies, food aid that disrupts commercial transactions, and domestic support that encourages overproduction that finds its way into international markets. In 2015, WTO member states agreed to eliminate all forms of export subsidies (WTO, 2015). Food aid continues to be an irritant in trade talks but is far less important in international markets than it used to be, and most governments are sensitive to the fact that food aid is useful as a tool for humanitarian interventions, making commercial objectives a lesser priority (Diaz-Bonilla, 2013). The continuing problem from the perspective of WTO member states is instead the high levels of domestic support provided by a few developed countries, especially the European Union, Japan and the USA. A majority of WTO member states, including some developed countries (primarily the big exporters: Canada, Australia and New Zealand), want to tighten WTO disciplines on domestic support. The current (disputed) text proposes some kind of overall cap on trade distorting support as well as measures that would give developing countries more space for domestic support while curbing the developed countries' use of the exempted programs listed in Annex 2 of the AoA (Greenville, 2017; ICTSD, 2017, 2018). As part of the Doha Round of trade talks at the WTO, a group of developing countries proposed a Special Safeguard Mechanism as a protection against dumping. The measure would allow developing countries to impose temporary tariff increases to limit the harm caused by import surges. There is no agreed definition of an import surge, but broadly they are unexpectedly large increases in import volumes measured over a defined, short-term, period (Morrison, 2007). The G33 also proposed the concept of Special Products, to create a category of food commodities whose markets developing countries would protect because of their importance to food security and rural employment.

These WTO debates are pertinent to the dumping debate, but they focus on just one of the several complex causes of dumping explored above. Government subsidies are important, but they are not the whole story. This focus leaves important factors unaddressed, including the oligopolistic market power of international grain traders and the urgency of better internalizing the environmental costs of agriculture, not least to limit losses and waste in food systems (High Level Panel of Experts on Food Security and Nutrition, 2014).

It is not uncommon for there to exist short-term price discrepancies between domestic and export markets. No market is perfect and commodity markets are rife with market failures and imperfections, such as imperfect or delayed transmission of information concerning supply and demand. Nor are there clear indicators that determine when a 'short-term discrepancy' becomes a chronic problem-economists disagree (High Level Panel of Experts on Food Security and Nutrition, 2011). The numbers presented in this article, however, do not record a short-term phenomenon. For over two decades, US agricultural commodities have been dumped in world markets, highlighting a price gap between costs of production and export prices that sometimes disappears, when world prices are especially high, but reappears as soon as prices drop.

Dumping destabilizes markets. Dumping is unpredictable. Dumping has destroyed agriculture and related industries in developing countries-one of the best documented examples is Haiti's domestic rice sector, which was buried in imported rice during the 1990s (Rakitoarisoa et al., 2011). In the past, governments were encouraged by economic advisors to overlook dumping because it provides cheap food imports for consumers. The economic argument is that countries can invest their domestic resources in other sectors if they have a cheap food supply (The World Bank Group, 1986). At the height of structural adjustment programs, agriculture was seen as a 'backward' sector, requiring too much labor for too little economic return. Advisors sought to get developing countries to invest in higher value-added export sectors instead (Mihevc, 1995; Mkandawire and Soludo, 2003; Chang, 2009). More recently, the World Bank and others have thought better of this neglect of agriculture (The World Bank, 2007). Other voices in economic development have persuaded governments that undermining domestic agriculture in developing countries is a mistake, not least because undermining agriculture undermines an important source of poverty-reducing growth (Lipton, 1993; Hazell et al., 2010; Timmer, 2015). Dumping destroys rural livelihoods and diminishes opportunities to build local infrastructure through local exchange (Rosset, 2006; Rakitoarisoa et al., 2011; Morrison and Mermigkas, 2014). Relying on dumped agricultural production also makes lowincome net food importing countries vulnerable to price spikes (Valdés and Foster, 2012). When prices on international markets rise sharply, poor and vulnerable countries can find themselves without a reliable supplier, as Liberia learned when its rice import contracts were broken by traders in the 2007-2008 food price crisis (Wise and Murphy, 2012). When the government was unable to pay higher prices for an already contracted shipment of rice, the trading company broke the contract, returned the money and left Liberia without the rice the government was relying on to protect access to food in the country. Persistent dumping undermines local production in ways that are not easily remedied because by lowering prices, dumping destroys profitability for local producers in the country receiving dumped commodities.

\section{Who benefits from dumping?}

The benefits of export-oriented agriculture tend to accrue to the largest actors, particularly the grain traders most directly involved in international markets. While farmers' planting decisions are locked in seasonally or even longer, grain traders are set up to react very quickly to changes in markets. These companies have vastly superior access to information, an advantage that is likely to increase in the era of Big Data in agriculture (Mooney, 2017). Although they have significant capital investments in commodity transport infrastructure, they can offset their risks with futures trading, and their global presence and market power gives them access to buyers and sellers around the planet (Murphy et al., 2012; Clapp and Isakson, 2018). Grain traders can profit when prices rise or when they fall, as long as they are successfully predicting the direction of change. Grain traders have strong risk management strategies, including access to global markets and vastly more information on market conditions. If the US soy harvest fails, they can source from Brazil or Argentina; if demand in China dips, they can look for customers in Malaysia instead. As importantly, grain traders are in the business of 
adding value to primary commodities, whether they are fattening animals with soy or turning corn into ethanol. Cheap grain is an input which the companies are happy to keep cheap.

The risks inherent in agricultural production, such as the unpredictable (and, more recently, erratic) meteorological conditions, fall on farmers. The risks of unstable markets, too, are a problem. Limiting production is not really an option if prices are expected to fall, as no individual farm is in a position to affect the market. This means farmers, quite rationally, tend to maximize production in the hopes that higher volume will compensate for lower prices. Many US farmers use the futures market to offset their risk but as individual operators, their presence is tiny. Futures contracts have grown increasingly expensive, too, as a result of deregulation, and prices are affected in the short-run by pressures that are not strongly linked to the supply and demand for physical commodities (De Schutter, 2010; Clapp, 2014). Deregulation of financial and commodity markets in the early 2000s enabled a rise in speculation on commodity markets and undermined price formation based on market fundamentals (High Level Panel of Experts on Food Security and Nutrition, 2011). While the Dodd-Frank financial reforms that followed the 2008 financial crisis included important reforms designed to rein in financial speculation, that legislation has been weakened by legal and congressional challenges. President Trump's administration is committed to further deregulation of financial markets.

\section{The 21st century challenges: food security and rising volatility}

The last 20 yr have seen important changes in international agricultural commodity trade. More food is grown, more food is traded internationally, and more countries are involved in growing and trading commodities (FAO, 2015). Production in Brazil, in particular, has surged, putting its production of soy and corn on a par with the previously dominant USA. There are more people in the world, in part because more people are living longer lives. More significantly from an international trade perspective, more people have larger incomes. Asia has overtaken Europe as the largest food-importing region (FAO, n.d.). Diets have changed as tens of millions of people have adapted and diversified their diets, eating relatively less food staples such as rice, and relatively more meat, fresh produce and processed foods (High Level Panel of Experts on Food Security and Nutrition, 2017b). At the same time, strong population growth in some of the world's poorest regions has kept demand strong for the three primary sources of calories worldwide (rice, corn and wheat). Meeting the steadily growing demand for food has exacerbated the unsustainable use of freshwater and topsoil and encouraged deforestation, while urbanization and climate change are shifting the geography of agricultural production and making output less predictable (Steinfeld et al., 2006; FAO, 2009; IPCC, 2014).

The numbers presented in this report show the extent of agricultural commodity dumping diminished during the periods of higher commodity prices in 2007-2008 and 2011-2012; despite rising costs of production, for a time most agricultural commodity prices rose faster and higher. Regions that depend heavily on agricultural commodity production and export profited from the brief moment of higher commodity prices; for example, in parts of Africa, much of Latin America and in India (Headey, 2011, 2014). The benefits were also felt in higher government revenues and improved conditions on farms for producers and farm workers (Wiggins and Keats, 2014). But urban consumers suffered and governments faced enormous political pressure to act quickly to bring food prices back down. A range of policies came up for review in the aftermath of the price crisis; public investment in agriculture, private investment in land, price stabilization measures and social safety nets all received policy attention and funding (Wise and Murphy, 2012, p. 38).

Over the last few years, commodity stock levels have started to climb again. There are few supply management policies in place to curb production and many commodity prices are again depressed in international markets. All is not as it was before. The long-term shifts in the underlying conditions for supply and demand have contributed to increased awareness of how vulnerable food systems are when they rely on a few global producers and exporters. The FAO announced in 2017 that the number of people living with food insecurity in the world has risen for the first time in a decade and that climate change has played a role in that spike, particularly in the drought that has plagued parts of Africa (FAO, 2017). Increasingly, food insecure countries, particularly in Africa, are becoming more food import dependent according to UNCTAD, making the state of international markets a critical factor in their food security (UNCTAD, 2016).

While the food price crisis refocused attention on the vulnerabilities of globally interdependent food systems and the need for better risk management, the current resumption of low prices and dumping underscore the need for comprehensive solutions that allow farmers to plan their production at fair and reasonably predictable prices. Most governments acknowledge that their food security rests on both local production and trade. It is essential that trade be governed by fair and transparent rules. A crucial first step is to protect food security from agricultural dumping.

While many in the USA would agree on the need for a better Farm Bill that ensures consumers get healthier food produced more sustainably, there is not yet sufficient consensus around programs to pay farmers fair prices for their production or to rein in oligopolistic markets. In any case, those measures will only succeed if there is also renewed attention to programs to manage supplies to address climate catastrophes and other supply and price shocks rather than simply seeking to export as much as possible for as long as possible. The Conservation Stewardship Program is an example of the kind of program that would move US agriculture away from dumping: it offers a whole farm approach supports climate-resilient strategies that support soil health, water quality, perennial grasses, sustainable livestock management and cover cropping. The Union of Concerned Scientists estimates the program is worth $\$ 4.7$ billion to taxpayers in the damage avoided through better management (Stanley, 2018). A second recent initiative could also make a difference to dumping: New Jersey Senator Cory Booker's proposed legislation to limit mergers in the agriculture sector. The bill would, impose a temporary moratorium on mergers and acquisitions between large farm, food, and grocery companies, and establish a commission to strengthen antitrust enforcement in the agribusiness industry', according to a summary put out by New Food Economy on 30 August 2018 (Bloch, 2018).

The return to dumping of US commodities by agribusiness occurs at a time when the US Government is challenging other countries' agricultural programs (as the USA has challenged China at the WTO for its support prices to corn farmers as well as India's use of support prices for its public stockholding and public food distribution programs). The US approach does not acknowledge the problems in US production and exports, leading to accusations of hypocrisy from trade partners. The 
aggressive US stance on developing countries' use of domestic support limits the chances for a successful outcome to the renegotiation of the AoA. The findings presented in this article underline the need for a new approach to global trade rules-an approach based on the imperative to protect, respect and fulfill the human right to food and to curb the power of transnational agribusinesses to protect more market power for farmers. New rules should respect the obligation on governments to protect food security at home, embrace the complex relationship of food systems to economic development, and recognize the importance of accountability in domestic politics in rich and poor countries alike.

Acknowledgement. Both authors especially want to thank Ben Lilliston, Daniel de la Torre Ugarte, Tim Wise and Harwood Schaffer for their thoughtful comments and Laurel Levin for her editorial assistance. We also want to recognize Mark Ritchie, who had the idea in the first place, and all those who have contributed to IATP's work on dumping over the years: Gigi DiGiacomo, Suzanne Wisniewski, Mary Beth Lake and Ben Lilliston.

\section{References}

Abbott PC, Hurt C and Tyner WE (2008) What's Driving Food Prices?. Oak Brook, IL: Farm Foundation, p. 82.

Abbott PC, Hurt C and Tyner WE (2011) What's Driving Food Prices in 2011? Oak Brook, IL: Farm Foundation.

Agricultural Marketing Service (n.d.) Grain Transportation Report Datasets. Washington, DC: U.S. Department of Agriculture. Available at https:// www.ams.usda.gov/services/transportation-analysis/gtr-datasets.

Alston JM and Sumner DA (2007) Perspectives on farm policy reform. Journal of Agricultural and Resource Economics 32, 1-19.

Barrett CB and Maxwell D (2005) Food Aid After Fifty Years. Abingdon, Oxon (UK): Routledge.

Bloch S (2018) A handful of companies control American agriculture. Cory Booker wants to change that. Available at https://newfoodeconomy.org/ cory-booker-agribusiness-merger-moratorium-antitrust-bill/ (Accessed 2 September 2018).

Bloomberg News (2018) China to Cancel More U.S. Soy Shipments as More Tariffs Loom. Available at https://www.bloomberg.com/news/articles/201807-03/china-to-cancel-more-u-s-soy-shipments-as-extra-tariff-looms (Accessed 27 September 2018).

Bodde D (1946) Henry A. Wallace and the ever-normal granary. Far Eastern Quarterly 5.

Campbell BM, Beare DJ, Bennett EM, Hall-Spencer JM, Ingram JSI, Jaramillo F, Ortiz R, Ramankutty N, Sayer JA and Shindell D (2017) Agriculture production as a major driver of the Earth system exceeding planetary boundaries. Ecology and Society 22, art8.

Chang H-J (2009) Rethinking public policy in agriculture: lessons from history, distant and recent. Journal of Peasant Studies 36, 477-515.

Clapp J (2014) Financialization, distance and global food politics. Journal of Peasant Studies 41, 797-814.

Clapp J and Helleiner E (2012) Troubled futures? The global food crisis and the politics of agricultural derivatives regulation. Review of International Political Economy 19, 181-207.

Clapp J and Isakson SR (2018) Risky returns: the implications of financialization in the food system. Development and Change 49, 437-460.

Cullather N (2011) The Hungry World. Cambridge: Harvard University Press.

De Schutter O (2010) Food Commodities Speculation and Food Price Crises (Briefing Note 02). Geneva: United Nations Special Rapporteur on the Right to Food.

Diaz-Bonilla E (2013) Agricultural Trade and Food Security: Some Thoughts About A Continuous Debate. Geneva: International Centre for Trade and Sustainable Development and the World Economic Forum.

DiGiacomo G (1998) U.S. Agricultural Exports Dumping Monitor 1998. Minneapolis: Institute for Agriculture and Trade Policy.

Downey L (2016) Inequality, Democracy, and the Environment. New York: NYU Press, pp. 115-164.

Economic Research Service. (2017). Most farmers receive off-farm income, but small-scale operators depend on it. Available at https://www.ers.usda.
gov/data-products/chart-gallery/gallery/chart-detail/?chartId=58426 (Accessed 24 September 2018).

Economic Research Service (2018) Highlights From the August 2018 Farm Income Forecast: Farm Sector Profits Expected To Decline in 2018 (Accessed 27 September 2018).

Economic Research Service (n.d.) Commodity Costs and Returns. Washington, DC: ERS, United States Department of Agriculture. Available at https:// www.ers.usda.gov/data-products/commodity-costs-and-returns.aspx.

FAO (2009) How to Feed the World 2050. Rome: FAO.

FAO (2015) The State of Agricultural Commodity Markets 2015-16. Rome: Food and Agriculture Organization of the UN.

FAO (2017) The State of Food Security and Nutrition in the World 2017. Rome: Food and Agriculture Organization of the United Nations. Retrieved from http://www.fao.org/state-of-food-security-nutrition/en/.

Farm Service Agency (2014) ARC/PLC Program. Available at https://www.fsa. usda.gov/programs-and-services/arcplc_program/index (Accessed 27 September 2018).

Foreign Agricultural Service (n.d.) Global Agricultural Trade System. Washington, DC: USDA Foreign Agricultural Service. Available at https:// apps.fas.usda.gov/gats/default.aspx.

Fox $\mathbf{J}$ and Haight $\mathbf{L}$ (n.d.). Subsidizing Inequality. Santa Cruz: Woodrow Wilson International Center for Scholars \& Centro de Investigacion y Docencia Economicas. Available at https:/www.wilsoncenter.org/sites/ default/files/Subsidizing\%20Inequality_0.pdf.

Glauber JW and Westhoff P (2015) 50 Shades of Amber. Presented at the American Economic Association, Boston.

Good K (2017) U.S. Ag Exports Remain Strong, But Global Share Declines as Destinations Have Changed (NAFTA, China). Available at https:// farmpolicynews.illinois.edu/2017/11/u-s-ag-exports-remain-strong-globalshare-declines-destinations-changed-nafta-china/ (Accessed 27 September 2018).

Greenville J (2017) Domestic Support to Agriculture and Trade. Geneva: ICTSD.

Hazell P, Poulton C, Wiggins S and Dorward A (2010) The future of small farms: trajectories and policy priorities. World Development 38, 1349-1361.

Headey D (2011) Was the global food crisis really a crisis? | International Food Policy Research Institute (IFPRI). Available at http://www.ifpri.org/publication/ was-global-food-crisis-really-crisis (Accessed 8 May 2014).

Headey D (2014) Food Prices and Poverty Reduction in the Long Run. Washington, DC: IFPRI.

Headey D and Fan S (2008) Anatomy of a crisis: the causes and consequences of surging food prices. Agricultural Economics 39, 375-391.

Heinrich Böll Stiftung, Rosa Luxembourg Stiftung, Friends of the Earth Europe (2017) Agrifood Atlas. Heinrich Böll Foundation, Berlin, Germany; Rosa Luxemburg Foundation, Berlin, Germany; Friends of the Earth Europe, Brussels, Belgium.

Hendrickson M and Heffernan W (2007) Concentration of Agricultural Markets, vol 21, pp. 311-328. Columbia, MO: University of Missouri.

Hendrickson M, Wilkinson J, Heffernan WD and Gronski R (2008) The global food system and nodes of power. SSRN Electronic Journal.

High Level Panel of Experts on Food Security and Nutrition (2011) Price Volatility and Food Security. Rome: High Level Panel of Experts of the UN Committee on World Food Security.

High Level Panel of Experts on Food Security and Nutrition (2014) Food Losses and Waste in the Context of Sustainable Food Systems (No. 8). Rome: High Level Panel of Experts of the UN Committee on World Food Security.

High Level Panel of Experts on Food Security and Nutrition (2017a) 2nd Note on Critical and Emerging Issues for Food Security and Nutrition. Rome: High Level Panel of Experts of the UN Committee on World Food Security.

High Level Panel of Experts on Food Security and Nutrition (2017b) Nutrition and Food Systems. Rome: High Level Panel of Experts of the UN Committee on World Food Security.

Howard PH (2016) Concentration and Power in the Food System: Who Controls What We Eat? New York: Bloomsbury Academic.

Hunter D (1989) Interview with Anne Kanten. In Hunter D (ed.) Minnesota Farm Advocate Oral History Project. Hawick, MN: Minnesota Historical Society. Available at http://collections.mnhs.org/cms/display?irn=10362520\&return $=\mathrm{q} \% 3 \mathrm{DAnne} \% 2520$ Kanten\#transcript 
ICTSD (2017) Options for WTO Negotiations on Agriculture Domestic Support. Geneva: International Centre for Trade and Sustainable Development.

ICTSD (2018) Achieving Progress in Multilateral Trade Negotiations on Agriculture. Geneva: International Centre for Trade and Sustainable Development.

IPCC (2014) Food Security and Food Production Systems. ipcc-wg2.gov. Geneva.

Kneen B (2002) Invisible Giant: Cargill and Its Transnational Strategies. London: Pluto Press.

Lau C, Schropp S and Sumner D (2015) The 2014 US Farm Bill and Its Effects on the World Market for Cotton (No. 58). Geneva: International Centre for Trade and Sustainable Development.

Levins RA (2000) Willard Cochrane and the American Family Farm. Lincoln, Nebraska: University of Nebraska Press.

Levins RA and Cochrane WW (1996) The Treadmill Revisited. Land Economics 72, 550-553.

Lipton M (1993) Urban bias: of consequences, classes and causality. Dx.Doi.org 29, 229-258.

Mahé LP and Roe TL (1996) The political economy of reforming the 1992 CAP reform. American Journal of Agricultural Economics 78, 1314-1323.

McMichael P (2004) The Global Restructuring of Agri-Food Systems. Ithaca, NY: Cornell University Press.

Mihevc J (1995) The Market Tells Them So. London: Zed Books.

Mkandawire T and Soludo CC (2003) In Mkandawire T and Soludo CC (eds), African Voices on Structural Adjustment. Trenton, Asmara, NJ: Africa World Press, pp. 1-16.

Mooney P (2017) Too Big to Feed. IPES-Food. Available at http://www.ipesfood.org/images/Reports/Concentration_FullReport.pdf

Morgan D (1979) Merchants of Grain. New York: Viking Press.

Morrison J (2007) The Extent and Impact of Import Surges on Developing Countries. Presented at the agritrade.org, Gilon, Switzerland.

Morrison J and Mermigkas G (2014) Import Surges and the Special Safeguard Mechanism Revisited (No. 15). Rome: Food and Agriculture Organization of the United Nations.

Murphy S (2006) Concentrated Market Power and Agricultural Trade (No. 1). Heinrich Böll Stiftung \& Misereor. Berlin, Germany.

Murphy S (2008a) Globalization and corporate concentration in the food and agriculture sector. Development 51, 527-533.

Murphy S (2008b) The Multilateral Trade and Investment Context for Biofuels: Issues and Challenges. International Institute for Environment and Development (London) and Institute for Agriculture and Trade Policy (Minneapolis).

Murphy S, Lilliston B and Lake M-B (2005) WTO agreement on agriculture: a decade of dumping. Institute for Agriculture and Trade Policy.

Murphy S, Burch D and Clapp J (2012) Cereal Secrets. Oxford: Oxfam.

National Cotton Council of America (n.d.) National Cotton Council of America Monthly Prices. National Cotton Council of America. Available at https://www.cotton.org/econ/prices/monthly.cfm.

OECD (2016) Producer and Consumer Support Estimates Database. Paris: Organization for Economic Cooperation and Development. Available at http://doi.org/10.1787/agr_pol-2016-en.

Orden D, Paarlberg R and Roe TL (1999) Policy Reform in American Agriculture. Chicago: University of Chicago Press.

Rakitoarisoa MA, Sharma R and Hallam D (2011) In Rakitoarisoa MA, Sharma R and Hallam D (eds), Agricultural Import Surges in Developing Countries. Rome: Food and Agriculture Organization of the United Nations.

Ray DE, Daniel and Tiller K (2003) Rethinking US Agricultural Policy. Knoxville: Agricultural Policy Analysis Centre.

Rayner G and Lang T (2013) Ecological Public Health. London: Routledge.

Ridley W and Devadoss S (2012) Analysis of the Brazil-USA cotton dispute. Journal of International Trade Law and Policy 11, 148-162.

Risk Management Agency (USDA) (2016) Stacked Income Protection Plan (STAX) for Upland Cotton. Available at https://www.rma.usda.gov/news/ currentissues/stax/staxfactsheet.pdf (Accessed 27 September 2018).

Ritchie M, Wisniewski S and Murphy S (2000) Dumping as A Structural Feature of US Agriculture: Can WTO Rules Solve the Problem? Minneapolis: Institute for Agriculture and Trade Policy.

Rockström J, Steffen W, Noone K, Persson Å, Chapin FS, Lambin EF, et al. (2009) A safe operating space for humanity. Nature 461, 472-475.
Rosset PM (2006) Food Is Different: Why We Must Get the WTO Out of Agriculture. Black Point, NS: Fernwood Publishing.

Schnepf R (2017) U.S. Farm Income Outlook for 2017. Congressional Research Service. Washington, D.C.

Scholar HH (1973) Federal Farm Policies Hit. Reading Eagle. Reading, PA. Available at https://news.google.com/newspapers?nid=ZuSUVyMx-TgC\&dat= 19731023\&printsec=frontpage\&hl=en.

Senate Agriculture, Nutrition and Forestry Committee (2008) Farm Bill: Investments for the Future. Available at https://www.agriculture.senate.gov/ imo/media/doc/2008_farm_bill_highlights.pdf (Accessed 27 September 2018).

Shaw DJ (2007) World Food Security. Basingstoke \& New York: Palgrave Macmillan.

Stanley P (2018) What Congress Does Next Could Cost Farmers and Taxpayers Billions. Union of Concerned Scientists. Available at https:// blog.ucsusa.org/science-blogger/what-congress-does-next-could-cost-farmersand-taxpayers-billions (Accessed 27 September 2018).

Steinfeld H, Gerber P, Wassenaar T, Castel V, Rosales M and de Haan C (2006) Livestock's Long Shadow. Rome: Food and Agriculture Organization of the United Nations.

Sumner DA (2003) Implications of the US Farm Bill of 2002 for agricultural trade and trade negotiations. The Australian Journal of Agricultural and Resource Economics 46, 99-122.

The World Bank (2007) World Development Report 2008: Agriculture for Development. Washington, DC: The World Bank.

The World Bank Group (1986) World Development Report 1986. New York: Oxford University Press.

Timmer CP (2010) Reflections on food crises past. Food Policy 35, 1-11.

Timmer CP (2015) Food Security and Scarcity: Why Ending Hunger is so Hard. Philadelphia: University of Pennsylvania Press.

Traoré F (2017) Domestic and trade policies affecting the world cotton market. In Bouët A and Laborde D (eds), Agriculture, Development, and the Global Trading System: 2000-2015. Washington, DC: International Food Policy Research Institute, pp. 193-230.

UNCTAD (2016) The State of Commodity Dependence 2016. Geneva. United Nations Conference on Trade and Development.

USDA (2012) USDA Census of Agriculture: 2012 Census Highlights. Washington, DC: United States Department of Agriculture. Available at https://agcensus.usda.gov/Publications/2012/Online_Resources/Highlights/ Farm_Economics/

Valdés A and Foster W (2012) Net Food-Importing Developing Countries (No. 43), Geneva: International Centre for Trade and Sustainable Development.

Wiggins S and Keats S (2014) Rural Wages in Asia. London: Overseas Development Institute.

Wilson J and Durisin M (2016) Betting the Farm and Losing: Banks Seek Collateral for Debts. Bloomberg. Available at https://www.bloomberg.com/ news/articles/2016-11-13/betting-the-farm-and-losing-banks-seek-collateralas-debts-rise

Wise TA (2004) The Paradox of Agricultural Subsidies: Measurement Issues, Agricultural Dumping, and Policy Reform (Working Paper No. 04-02). Boston: GDAE, Tufts University.

Wise TA (2005) Identifying the Real Winners from U.S. Agricultural Policies (No. Working Paper No. 05-07). Boston: Global Development and Environment Institute. Available at http://www.ase.tufts.edu/gdae/Pubs/ wp/05-07RealWinnersUSAg.pdf

Wise TA (2010) Agricultural Dumping Under NAFTA: Estimating the Costs of U.S. Agricultural Policies to Mexican Producers, 7th Edn. Washington, DC: Woodrow Wilson International Center for Scholars.

Wise TA and Murphy S (2012). Resolving the Food Crisis. Boston and Minneapolis: Global Development and Environment Institute and Institute for Agriculture and Trade Policy, p. 38.

Wise TA and Rakocy B (2010) Hogging the Gains From Trade: The Real Winners From U.S. Trade and Agricultural Policies (No. Policy Brief 10-01 m). Boston: Global Development and Environment Institute.

Wolfe R (1998) Farm Wars. Houndmills, England: Macmillan Press.

WTO (2015) Nairobi Ministerial Declaration (No. WT/MIN(15)/DEC). Nairobi: World Trade Organization.

WTO (1994) Agreement on Agriculture. Geneva. Available at http://www.wto.org. 


\section{Appendix}

\section{Dumping calculations}

Table 1. Wheat

\begin{tabular}{|c|c|c|c|c|c|c|}
\hline Year & $\begin{array}{l}\text { Farmer Production } \\
\text { Costs (US\$/Bu) }\end{array}$ & $\begin{array}{l}\text { Govt Support Costs } \\
\text { (US\$/Bu) }\end{array}$ & $\begin{array}{l}\text { Transportation and } \\
\text { Handling (US\$/Bu) }\end{array}$ & $\begin{array}{l}\text { Full Cost } \\
(\$ / B u)\end{array}$ & $\begin{array}{l}\text { Export Price } \\
\qquad(\$ / \mathrm{Bu})\end{array}$ & $\begin{array}{l}\text { Percent of Export } \\
\text { Dumping (\%) }\end{array}$ \\
\hline 2005 & 5.20 & 0.06 & 0.86 & 6.12 & 4.40 & 28 \\
\hline 2006 & 6.53 & 0.30 & 0.90 & 7.73 & 5.52 & 29 \\
\hline 2007 & 6.20 & 0.24 & 0.72 & 7.16 & 7.03 & 2 \\
\hline 2008 & 6.72 & 0.37 & 0.94 & 8.03 & 8.88 & -11 \\
\hline 2009 & 6.58 & 0.73 & 1.24 & 8.55 & 6.51 & 24 \\
\hline 2010 & 5.68 & 0.37 & 1.36 & 7.41 & 6.72 & 9 \\
\hline 2011 & 7.65 & 0.57 & 1.46 & 9.68 & 9.07 & 6 \\
\hline 2012 & 6.89 & 0.50 & 1.44 & 8.83 & 8.96 & -1 \\
\hline 2013 & 8.02 & 0.61 & 1.50 & 10.14 & 8.76 & 14 \\
\hline 2014 & 8.57 & 0.45 & 1.69 & 10.72 & 8.31 & 23 \\
\hline 2015 & 7.73 & 0.39 & 1.30 & 9.43 & 6.40 & 32 \\
\hline 2016 & 5.89 & 0.39 & 1.57 & 7.86 & 5.47 & 30 \\
\hline 2017 & 7.34 & 0.36 & 2.14 & 9.85 & 6.12 & 38 \\
\hline
\end{tabular}

Table 2. Soybeans

\begin{tabular}{|c|c|c|c|c|c|c|}
\hline Year & $\begin{array}{c}\text { Farmer Production } \\
\text { Costs (US\$/Bu) }\end{array}$ & $\begin{array}{l}\text { Govt Support Costs } \\
\text { (US\$/Bu) }\end{array}$ & $\begin{array}{l}\text { Transportation and } \\
\text { Handling (US\$/Bu) }\end{array}$ & $\begin{array}{l}\text { Full Cost } \\
(\$ / B u)\end{array}$ & $\begin{array}{l}\text { Export Price } \\
\quad(\$ / \mathrm{Bu})\end{array}$ & $\begin{array}{l}\text { Percent of Export } \\
\text { Dumping (\%) }\end{array}$ \\
\hline 2005 & 5.68 & -0.03 & 0.84 & 6.48 & 6.56 & -1 \\
\hline 2006 & 6.05 & -0.02 & 1.02 & 7.04 & 6.43 & 9 \\
\hline 2007 & 6.60 & 0.06 & 0.97 & 7.63 & 8.82 & -16 \\
\hline 2008 & 7.78 & 0.50 & 1.41 & 9.69 & 12.85 & -33 \\
\hline 2009 & 7.62 & 0.36 & 1.09 & 9.07 & 10.95 & -21 \\
\hline 2010 & 7.75 & 0.32 & 1.10 & 9.17 & 11.14 & -22 \\
\hline 2011 & 8.71 & 0.52 & 1.14 & 10.36 & 13.79 & -33 \\
\hline 2012 & 10.42 & 0.51 & 1.21 & 12.14 & 15.41 & -27 \\
\hline 2013 & 10.87 & 0.46 & 0.95 & 12.28 & 14.94 & -22 \\
\hline 2014 & 9.94 & 0.36 & 1.25 & 11.54 & 13.55 & -17 \\
\hline 2015 & 9.90 & 0.33 & 1.20 & 11.43 & 10.24 & 10 \\
\hline 2016 & 8.53 & 0.27 & 1.22 & 10.02 & 10.42 & -4 \\
\hline 2017 & 9.08 & 0.37 & 1.11 & 10.56 & 10.13 & 4 \\
\hline
\end{tabular}


Table 3. Corn

\begin{tabular}{|c|c|c|c|c|c|c|}
\hline Year & $\begin{array}{c}\text { Farmer Production } \\
\text { Costs (US\$/Bu) }\end{array}$ & $\begin{array}{l}\text { Govt Support Costs } \\
\text { (US\$/Bu) }\end{array}$ & $\begin{array}{l}\text { Transportation and } \\
\text { Handling (US\$/Bu) }\end{array}$ & $\begin{array}{l}\text { Full Cost } \\
\text { (\$/Bu) }\end{array}$ & $\begin{array}{l}\text { Export Price } \\
(\$ / \mathrm{Bu})\end{array}$ & $\begin{array}{l}\text { Percent of Export } \\
\text { Dumping (\%) }\end{array}$ \\
\hline 2005 & 2.60 & 0.40 & 0.60 & 3.60 & 2.50 & 31 \\
\hline 2006 & 2.97 & 0.01 & 0.70 & 3.68 & 3.12 & 15 \\
\hline 2007 & 3.10 & -0.02 & 0.65 & 3.74 & 4.19 & -12 \\
\hline 2008 & 3.68 & 0.18 & 0.82 & 4.67 & 5.69 & -22 \\
\hline 2009 & 3.53 & 0.17 & 0.66 & 4.36 & 4.19 & 4 \\
\hline 2010 & 3.46 & 0.14 & 0.67 & 4.27 & 4.76 & -11 \\
\hline 2011 & 4.20 & 0.24 & 0.71 & 5.14 & 7.40 & -44 \\
\hline 2012 & 5.54 & 0.26 & 0.61 & 6.41 & 7.57 & -18 \\
\hline 2013 & 4.34 & 0.22 & 0.55 & 5.10 & 6.65 & -30 \\
\hline 2014 & 4.06 & 0.16 & 0.93 & 5.14 & 4.92 & 4 \\
\hline 2015 & 4.04 & 0.17 & 0.71 & 4.92 & 4.33 & 12 \\
\hline 2016 & 3.62 & 0.15 & 0.61 & 4.38 & 4.05 & 8 \\
\hline 2017 & 3.61 & 0.15 & 0.58 & 4.33 & 3.94 & 9 \\
\hline
\end{tabular}

Table 4. Rice

\begin{tabular}{|c|c|c|c|c|c|c|}
\hline Year & $\begin{array}{l}\text { Farmer Production } \\
\text { Costs (US\$/Cwt) }\end{array}$ & $\begin{array}{c}\text { Govt Support Costs } \\
\text { (US\$/Cwt) }\end{array}$ & $\begin{array}{l}\text { Transportation and } \\
\text { Handling (US\$/Cwt) }\end{array}$ & $\begin{array}{l}\text { Full Cost } \\
\text { (\$/Cwt) }\end{array}$ & $\begin{array}{l}\text { Export Price } \\
\text { (\$/Cwt) }\end{array}$ & $\begin{array}{c}\text { Percent of Export } \\
\text { Dumping (\%) }\end{array}$ \\
\hline 2005 & 9.91 & 0.50 & 9.25 & 19.66 & 16.52 & 16 \\
\hline 2006 & 9.46 & 0.09 & 10.05 & 19.60 & 19.48 & 1 \\
\hline 2007 & 9.47 & 0.04 & 9.49 & 19.00 & 21.59 & -14 \\
\hline 2008 & 11.47 & 0.14 & 21.50 & 33.12 & 36.50 & -10 \\
\hline 2009 & 11.11 & 0.22 & 14.51 & 25.84 & 27.91 & -8 \\
\hline 2010 & 11.79 & 0.25 & 15.25 & 27.29 & 26.55 & 3 \\
\hline 2011 & 13.13 & 0.30 & 15.88 & 29.31 & 29.28 & 0 \\
\hline 2012 & 12.59 & 0.24 & 12.86 & 25.69 & 27.16 & -6 \\
\hline 2013 & 12.25 & 0.24 & 14.47 & 26.96 & 29.67 & -10 \\
\hline 2014 & 12.36 & 0.28 & 17.10 & 29.74 & 29.10 & 2 \\
\hline 2015 & 12.00 & 0.22 & 14.39 & 26.61 & 25.29 & 5 \\
\hline 2016 & 11.98 & 0.26 & 14.48 & 26.72 & 23.87 & 11 \\
\hline 2017 & 11.83 & 0.27 & 11.55 & 23.65 & 23.05 & 3 \\
\hline
\end{tabular}


Table 5. Cotton

\begin{tabular}{|c|c|c|c|c|c|}
\hline Year & $\begin{array}{l}\text { Farmer Production Costs } \\
\text { (US\$/pound) }\end{array}$ & $\begin{array}{l}\text { Govt Support Costs } \\
\text { (US\$/pound) }\end{array}$ & $\begin{array}{c}\text { Full Cost } \\
\text { (US\$/pound) }\end{array}$ & $\begin{array}{l}\text { Export Price } \\
\text { (\$/pound) }\end{array}$ & $\begin{array}{l}\text { Percent of Export } \\
\text { Dumping (\%) }\end{array}$ \\
\hline 2005 & 0.67 & 0.15 & 0.82 & 0.57 & 30 \\
\hline 2006 & 0.81 & 0.17 & 0.98 & 0.60 & 39 \\
\hline 2007 & 0.73 & 0.02 & 0.75 & 0.74 & 2 \\
\hline 2008 & 1.08 & 0.21 & 1.30 & 0.61 & 53 \\
\hline 2009 & 1.11 & 0.04 & 1.16 & 0.78 & 33 \\
\hline 2010 & 0.94 & 0.04 & 0.98 & 1.65 & -69 \\
\hline 2011 & 1.51 & 0.11 & 1.61 & 1.00 & 38 \\
\hline 2012 & 1.20 & 0.07 & 1.28 & 0.88 & 31 \\
\hline 2013 & 1.38 & 0.09 & 1.47 & 0.91 & 38 \\
\hline 2014 & 1.22 & 0.12 & 1.33 & 0.71 & 47 \\
\hline 2015 & 0.92 & 0.14 & 1.06 & 0.71 & 33 \\
\hline 2016 & 0.90 & 0.06 & 0.96 & 0.83 & 14 \\
\hline 2017 & 0.92 & 0.07 & 0.98 & 0.87 & 12 \\
\hline
\end{tabular}

Notes on calculations: The government support cost and the cost of transportation and handling are added to the farmer production cost to calculate the full cost of production. The percent of export dumping is the difference between the full cost of production and the export price, divided by the full cost of production. Sources: Farmer production costs are from USDA Commodity Costs and Returns, https://www.ers.usda.gov/data-products/commodity-costs-and-returns.aspx. Government Support Costs are from OECD Producer Support Estimates Database, http://www.oecd.org/tad/agricultural-policies/producerandconsumersupportestimatesdatabase.htm. Transportation and export prices are based on information in USDA

Agricultural Marketing Services Grain Transportation Report Datasets. For wheat, corn and soy, we used Table 2: Market Update: US Origins to Export Position Price Spreads. For rice we used Rice Yearbook, Table 17: Milled rice: Average price, f.o.b. mills, at selected US milling center. For cotton, we used the National Cotton Council of America's A Index of global prices, available at http://www.cotton.org/econ/prices/monthly.cfm. 